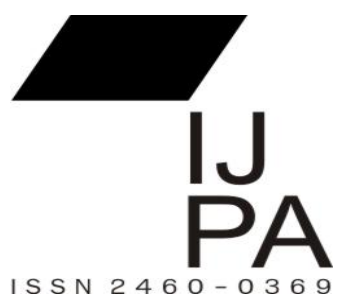

\title{
TIGA TAHUN PEMERINTAHAN JOKOWI ANALISA KINERJA DAN PENGELOLAAN SISTEM POLITIK
}

\author{
Efriza \\ Sekolah Tinggi Ilmu Pemerintahan Abdi Negara (STIP-AN) \\ Jakarta \\ efriza.riza@gmail.com
}

\begin{abstract}
This paper attempts to evaluate the performance of the political system of Jokowi government. According to the authors, Jokowi-JK government today has quite managed to prove the consistency of its performance and that is the implementation of the spirit of the cabinet work, but failed in the commitment of the cabinet formation of work such as not sharing power. This study found that manage the territory support of Jokowi more likely to choose the concept of win-win solution, to bring together the diverse interests of a demand towards the political system Perspective theory applied is the Political System Analysis of David Easton and Structural and Functional Analysis of Gabriel Almond; to explain the working of the political system of Jokowi governance.
\end{abstract}

Keywords: Political Systems, Political Systems and Environment, Jokowi Government

\begin{abstract}
Abstrak: Tulisan ini mencoba mengevaluasi kinerja sistem politik pada pemerintahan Jokowi. Menurut penulis, pemerintahan Jokowi-JK saat ini telah cukup berhasil membuktikan konsistensi kinerja dan kerjanya yang merupakan implementasi dari semangat kabinet kerja, tetapi gagal dalam komitmen pembentukan kabinet kerjanya seperti tidak bagi-bagi kekuasaan. Penelitian ini menemukan bahwa dalam mengelola wilayah dukungan Jokowi lebih cenderung memilih konsep win-win solution, untuk mempertemukan beragam kepentingan dari suatu tuntutan terhadap sistem politik. Perspektif teori yang diterapkan adalah Analisis Sistem Politik dari David Easton dan Analisis Struktural Fungsional dari Gabriel Almond; untuk menjelaskan kerja sistem politik dari pemerintahan Jokowi.

Kata Kunci: Sistem Politik, Sistem Politik dan Lingkungan, Pemerintahan Jokowi
\end{abstract}




\section{PENDAHULUAN}

Penulisan dalam penelitian ini berupa penelitian atas pengelolaan sistem politik di era Presiden Joko Widodo (Jokowi) dan kinerja pemerintahannya selama 3 (tiga) tahun. Mengawali tulisan ini dibuka dengan sebuah pernyataan bahwa sistem pemerintahan berbeda dengan sistem politik. Jika sistem pemerintahan merupakan struktur dan cara kerja atau mekanisme pemerintahan (trias politika: Eksekutif, Legislatif, dan Yudikatif; Pusat, Provinsi, Kabupaten, Kecamatan, dan Kelurahan) sementara sistem politik adalah keseluruhan atau kumpulan bagianbagian yang membentuk sistem politik. Jadi, sistem pemerintahan adalah salah satu bagian dari sistem politik.

Pengertian yang mendasari penelitian ini adalah penafsiran Andrew Heywood yang menyatakan bahwa sistem politik adalah sebuah istilah yang mencakup tidak hanya mekanisme dalam pemerintahan dan institusi-institusi di dalam negara, tetapi juga struktur dan proses dan bagaimana interaksinya dengan masyarakat yang lebih luas (Andrew Heywood, 2014: 470). Berbicara Sistem Politik tentu tak bisa dikesampingkan dari konsep analisis sistem politik model David Easton dengan analisis sistem politik secara struktural fungsional model Gabriel Almond. Kedua model ini coba diuraikan dengan menggunakan konsep sistem politik yang dijalankan di Indonesia utamanya berdasarkan Amandemen UUD 1945. Seperti tergambarkan dari judul penulisan ini bahwa penelitian ini menguraikan evaluasi terhadap kinerja sistem politik di era pemerintahan Jokowi. Suatu penelitian tentu memiliki batas waktu, oleh karena itu penulisan ini memiliki batasan waktu penelitian tiga tahun lebih atau tepatnya hingga Februari 2018 (selesainya penulisan ini). Pada akhirnya, pembahasan dalam penelitian ini akan mengarahkan pemahaman mengenai bagaimana kinerja pemerintahan Jokowi-JK setelah \pm 3 tahun memerintah?

Penelitian ini dirancang menggunakan pendekatan kualitatif dengan teknik pengumpulan data terdiri atas hasil wawancara mendalam (in-depth interview) sebagai data primer dan studi pustaka merupakan data sekunder. Setelah teknik pengumpulan data dilakukan maka data tersebut akan diolah, dianalisis dan dilakukan interpretasi data, sehingga akan menghasilkan suatu temuan atau hasil penelitian yang akan menjawab pertanyaan penelitian yang diajukan, (Haris Herdiansyah, 2010; Sanipah Faisal, 2008). 
Dari seluruh proses penelitian ini dihasilkan temuan penelitian bahwa, dalam pengelolaan sistem politiknya Presiden Jokowi memiliki konsistensi untuk kerja dan kerjanya masih dalam taraf berhasil, ini menunjukkan kesesuaian semangat yang didengungkan yakni sebagai kabinet kerja. Sedangkan, dari sisi analisa yang lebih sempit yakni dari sisi Pemerintahannya, tampak bahwa Presiden Jokowi memperoleh dukungan besar dari masyarakat karena konsistensi kinerjanya tetapi pengelolaan pemerintahannya masih terjebak pada upaya bagi-bagi kekuasaan tanpa mengedepankan yang menjadi prinsip awal pemerintahannya, seperti koalisi ramping dan tidak adanya rangkap jabatan di partai politik.

\section{SISTEM POLITIK INDONESIA}

Ketika kita mempelajari dan cermati model sistem politik Easton tampak jelas bahwa pada prinsipnya adalah merupakan proses melingkar, yaitu Masukan (inputs) berupa tuntutan dan dukungan, yang mana dari input ini --- Diproses (a political system) --- yang menghasilkan Keluaran (outputs) berupa keputusan-keputusan atau kebijakan-kebijakan. Output yang dihasilkan itu menjadi Umpan Balik (feedback) untuk sebuah proses bekerjanya sistem politik yang baru. Begitu seterusnya, (Parafrasa: Beddy Iriawan Maksudi, 2012).

Sementara berdasarkan analisis Struktural Fungsional dari Almond menjelaskan mengenai hubungan antara struktur dan fungsi antara proses dan kebijakan serta tata cara kerja sistem tersebut. Dalam membahas struktur Almond menyatakan terdapat 6 (enam) struktur atau lembaga politik yang terdiri dari suprastruktur seperti lembaga legislatif, eksekutif, dan lembaga yudikatif, serta birokrasi sebagai pembantu pemerintah; dan infrastruktur politik terdiri atas partai politik dan kelompok kepentingan.

Sementara terkait dengan proses dan kebijakan serta tata cara kerja sistem tersebut tampak bahwa analisis Almond lebih konkrit dibandingkan model Easton, misalnya jika diaplikasikan versinya Almond dalam konsep Easton maka, fungsi artikulasi kepentingan, agregasi kepentingan, dan komunikasi politik berkaitan erat dengan tuntutan dan dukungan yang masuk melalui mekanisme input. Sementara itu, conversion functions alias fungsi konversi merupakan "kotak" a political system versi Easton. Terakhir, fungsi output bukan berupa keputusan-keputusan atau kebijakan-kebijakan, melainkan berupa tiga fungsi yang dimiliki oleh tiga lembaga dalam trias politica (lembaga legislatif, eksekutif, dan yudikatif), yaitu fungsi pembuatan kebijakan, penerapan kebijakan, dan pengujian/penghakiman kebijakan. Mengenai 
penjelasan atas tuntutan dan dukungan yang dimaksud Almond, maka dapat kita kategorikan dalam tiga aras penjelasan yaitu, input, konversi, dan output (Parafrasa: Ikhsan Darmawan, 2013: 3, dan Seta Basri, 2013: 13). Dari rumusan kedua ilmuwan tersebut dalam versi kerja sistem politik Indonesia, menurut Penulis sendiri berdasarkan hasil elaborasi kedua pemikiran tersebut, maka dapat digambarkan sebagai berikut ini.

\section{Gambar 1.1 Sistem Politik Indonesia Pascaamandemen UUD 1945}

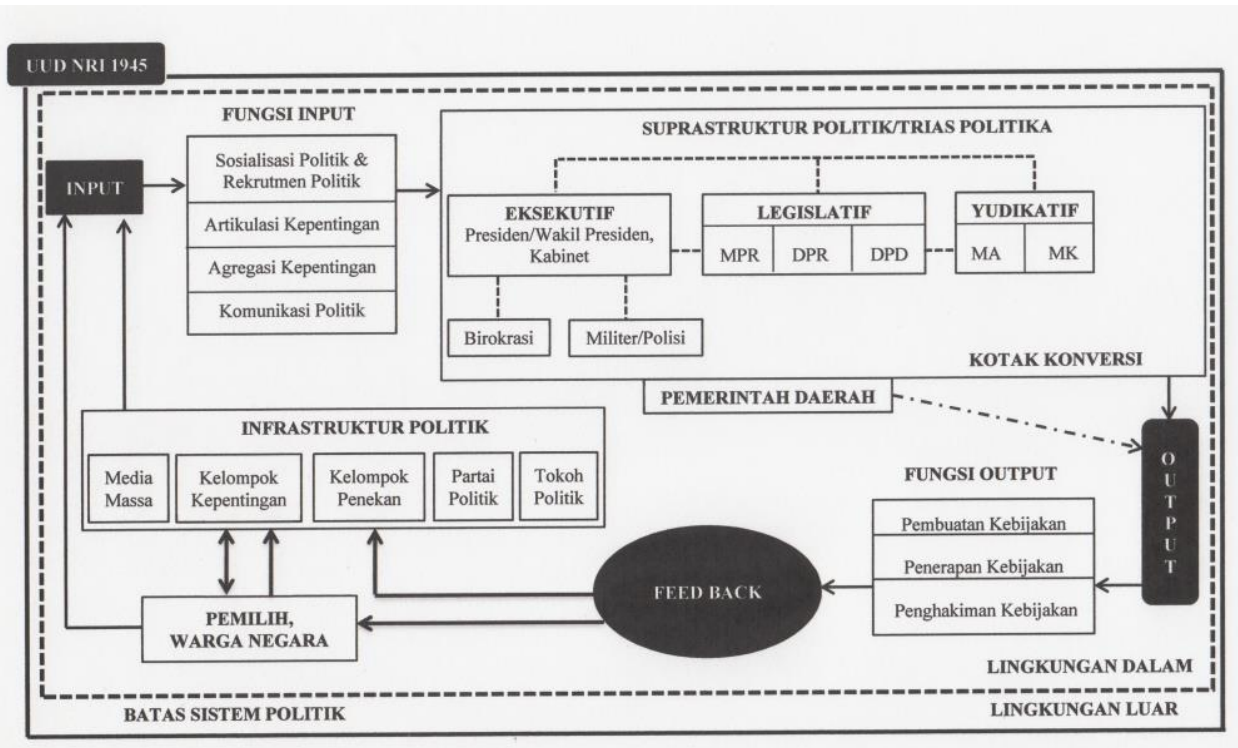

(Sumber: pengembangan dari Eep Saefulloh Fatah, 2014)

Sementara itu, dari segi fungsi dan hirarki dari lembaga-lembaga negara berdasarkan hasil amandemen UUD 1945 dapat dibedakan atas tigs lapis sebagai berikut: organ lapis pertama dapat disebut sebagai lembaga tinggi negara, sementara, organ lapis kedua disebut sebagai lembaga negara saja, sedangkan organ lapis ketiga merupakan lembaga daerah; hal itu seperti terlihat pada Gambar 1.2 Hirarki Lembaga-lembaga Negara, di bawah ini. 


\section{Gambar 1.2 Hirarki Lembaga-lembaga Negara}

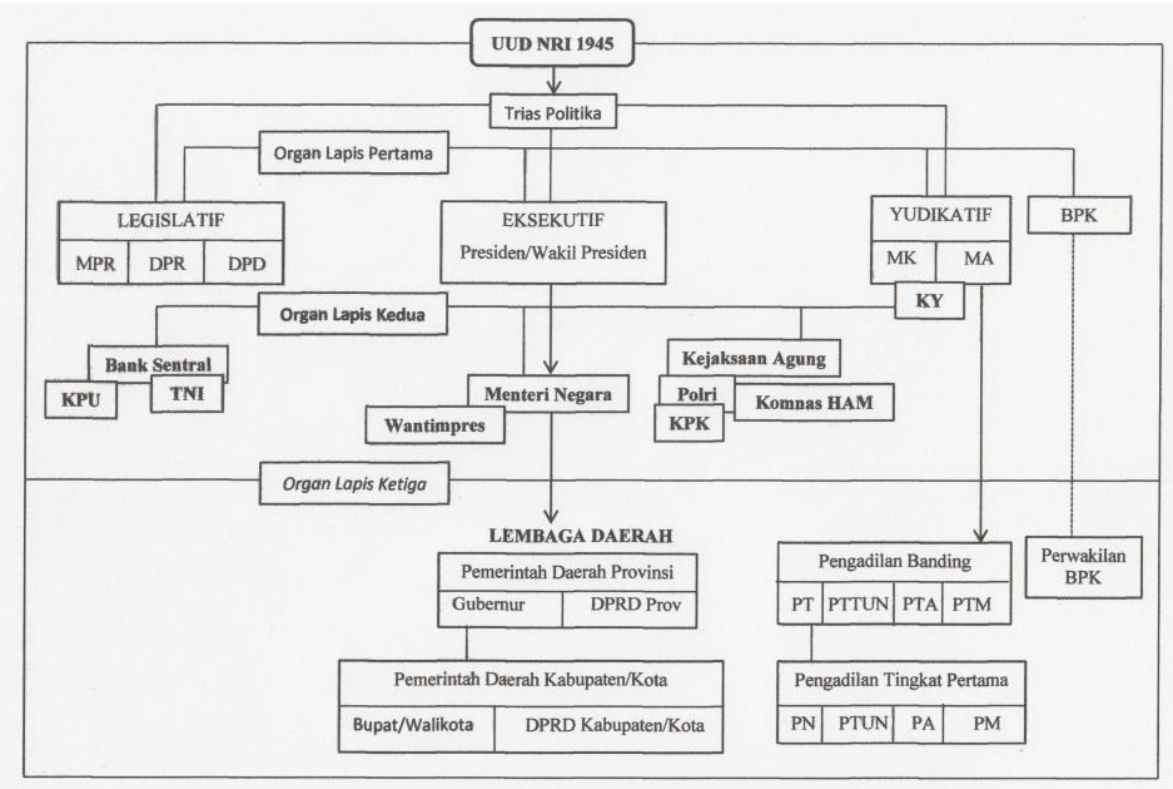

(Sumber: pengembangan dari Jimly Asshiddiqie, 2012: 145)

Setelah dilakukan amandemen UUD 1945 tidak ada lagi sebutan lembaga tertinggi dan lembaga tinggi negara, yang ada merupakan bentuk sejajar antar lembaga negara. Amandemen UUD 1945 juga menganut paham supremasi konstitusi bukan supremasi parlemen, sehingga tidak adanya pembagian kekuasaan yang bersifat horizontal (dengan division of power) melainkan yang bersifat vertikal (dengan separation of power dan bersamaan terwujudnya hubungan checks and balances). Untuk memudahkan pengertian, organ-organ konstitusi lapis pertama dapat disebut sebagai lembaga tinggi negara, yaitu: Presiden dan Wakil Presiden, DPR, DPD, MPR, MK, MA, dan BPK.

Organ lapis kedua disebut lembaga negara saja. Ada yang mendapatkan kewenangannya dari UUD, dan ada pula yang mendapatkan kewenangannya dari UU. Yang mendapatkan kewenangan dari UUD, misalnya, adalah KY, TNI, dan Kepolisian Negara; sedangkan lembaga yang sumber kewenangannya adalah UU, misalnya, adalah Komnas HAM, KPI, dsb. Kedudukan kedua jenis lembaga negara tersebut sebanding satu sama lain. Hanya saja, kedudukannya meskipun tidak lebih tinggi, tetapi jauh lebih kuat. Keberadaannya disebutkan secara eksplisit 
dalam UUD, sehingga tidak dapat ditiadakan atau dibubarkan hanya karena kebijakan pembentukan UU. Lembaga-lembaga negara sebagai organ lapis kedua itu adalah: Menteri Negara, TNI, Kepolisian Negara, KY, KPU, dan Bank Sentral.

Yang perlu dipahami adalah derajat protokoler kelompok organ konstitusi pada lapis kedua tersebut di atas jelas berbeda dari kelompok organ konstitusi lapis partama. Organ lapis kedua ini dapat disejajarkan dengan posisi lembaga-lembaga negara yang dibentuk berdasarkan UU, seperti Komnas HAM, KPK, KPI, Komisi Pengawas Persaingan Usaha (KPPU), Komisi Kebenaran dan Rekonsiliasi (KKR), Konsil Kedokteran, dsb. Organ lapis kedua ini juga termasuk kategori lembaga negara yang sumber kewenangannya berasal dari regulator atau pembentuk peraturan di bawah UU. Misalnya, Komisi Hukum Nasional, dan Komisi Ombudsman Nasional dibentuk berdasarkan Keputusan Presiden belaka. Artinya keberadaannya secara hukum hanya didasarkan atas kebijakan Presiden (presidental policy) atau beleid presiden. Jika Presiden hendak membubarkannya lagi, maka tentu presiden berwenang untuk itu. Artinya, keberadaannya sepenuhnya bergantung kepada beleid Presiden.

Organ lapis ketiga adalah lembaga daerah. Yang terdiri atas: Pemerintahan Daerah Provinsi: Gubernur dan DPRD Provinsi; Pemerintahan Daerah Kabupaten: Bupati, dan DPRD Kabupaten; dan Pemerintahan Daerah Kota: Walikota dan DPRD Kota. Lembaga daerah tersebut pada pokoknya terdiri atas tiga susunan pemerintahan, yaitu: (i) pemerintahan daerah provinsi; (ii) pemerintahan daerah kabupaten; dan (iii) pemerintahan daerah kota, yang masing-masing terdiri atas Kepala Pemerintahan Daerah dan DPRD setempat. Pemerintahan daerah secara bersama-sama ataupun jabatan kepala pemerintah daerah dan DPRD masing-masing tingkatan, secara sendiri-sendiri ataupun secara bersama-sama adalah merupakan institusi yang bersifat tersendiri. Analisis Sistem Politik secara Struktur Fungsional ini akan digunakan untuk menjelaskan pokok pertanyaan yang diajukan yaitu: bagaimana kinerja pemerintahan Jokowi-JK setelah \pm 3 tahun memerintah, uraiannya sebagai berikut.

\section{EVALUASI DAN TANTANGAN KERJA DAN KINERJA PEMERINTAHAN JOKOWI}

A. Mekanisme Kerja antar Suprastruktur Politik dan dengan Infrastruktur Politik

Jokowi adalah Presiden Indonesia ke-7, sama seperti SBY, Jokowi juga a leader by constitution. Menurut catatan Tjipta Lesmana bahwa gaya kepemimpinan Jokowi merupakan antitesis dari kepemimpinan penguasa politik Indonesia. Jokowi memang pemimpin yang keluar 
dari "pakem" penguasa politik di Indonesia. Ia sosok yang merakyat, senang turun langsung melalui aksi blusukannya ke kampung-kampung kumuh dan senang becek, sederhana penampilannya dalam tutur kata maupun kehidupannya, (Parafrasa: Tjipta Lesmana, 2014). Walaupun terkesan memiliki gaya berbicara apa adanya, seolah itu adalah yang sesungguhnya, tapi Jokowi adalah seorang komunikator politik dengan konteks tinggi (high context). Penggunaan bahasa bersayap, atau bahasa verbal yang tidak to the point, sering digunakannya, (Efriza, 2017: 190).

Ketika Pilpres 2014, terjadi persaingan keras antar dua kubu pasangan calon yaitu Prabowo-Hatta Rajasa dengan Jokowi-JK. Persaingan keras ini ternyata terbawa hingga ke Senayan maka terjadilah polarisasi dua kekuatan koalisi itu di parlemen. Polarisasi koalisi yang terjadi sesuai preferensi dukungan capres dan cawapres yang mana KIH sebagai pendukung pasangan Jokowi-JK sesuai dukungan partai politik di DPR diusung oleh PDIP, Nasdem, PKB, dan Hanura dengan total jumlah dukungan anggota parlemen sebanyak 207 anggota atau total suara di parlemen sebesar 36,96 persen. Sedangkan KMP pendukung pasangan Prabowo-Hatta Rajasa yang didukung partai politik di DPR pengusungnya adalah Gerindra, Golkar, PPP, PAN, PKS, dan Partai Demokrat (klaimnya netral) menguasai jumlah dukungan anggota parlemen sebanyak 353 anggota atau total suara di parlemen sebesar 63,03 persen. Menghadapi pusaran konflik KIH dan KMP dalam parlemen, ternyata Koalisi Pendukung Jokowi mengalami kekalahan demi kekalahan dengan skor telak yaitu 6-0, seperti: Penetapan UU MD3, Penetapan Tata Tertib DPR, Pemilihan Pimpinan DPR, Pemilihan Pimpinan Komisi dan Alat Kelengkapan DPR, Penetapan UU Pilkada (lewat DPRD), dan Pemilihan Pimpinan MPR.

Menyadari bahwa tidak mudah menjalankan politik pemerintahan dengan hanya sedikit kekuatan di parlemen, konsekuensinya Jokowi akhirnya mengabaikan koalisi tanpa syarat yang digembar-gemborkannya saat Pilpres 2014, ini dibuktikan oleh: Pertama, pemanfaatan konflik dari kepengurusan PPP atas perbedaan manuver dukungan di Pilpres 2014. KIH yang dari awal telah bermanuver untuk membangun kekuatan baru di parlemen memperluas dukungan partai koalisinya dengan bergabungnya PPP versi Romahurmuziy, respons pun dilakukan dengan menyediakan kursi dari paket calon pimpinan MPR, bahkan juga kepercayaan untuk menduduki kursi kementerian agama. 
Kedua, setahun pemerintahannya Presiden Jokowi sibuk melakukan konsolidasi politik, ia pun kembali melakukan hal yang dilakukan sebelumnya oleh SBY yaitu melanggengkan koalisi gemuk, konsekuesinya lagi-lagi prinsip koalisi tanpa syarat tidak mungkin lagi dapat diteruskan setelah dirangkulnya beberapa partai di KMP menjadi koalisi pendukung pemerintahan seperti PAN dan Partai Golkar. Tentu konsekuensinya, pihak koalisi pendukung Jokowi-JK perlu berbagi sumber daya, sebab, there is no such thing as free lunch, untuk mengakomodasinya Jokowi membagi kursi dalam reshuffle kabinet jilid II untuk mengakomodir bergabungnya PAN dan Partai Golkar sebagai pendukung pemerintahan sehingga masing-masing partai memperoleh 1 kursi kementerian. Dengan masuknya PAN dan Partai Golkar sebagai pendukung pemerintah, maka otomatis KIH dan KMP bubar, malah yang terjadi adalah Partai-partai Pendukung Pemerintahan (P4), (Warta Kota, 2015).

Ketiga, Jokowi kembali gagal menunjukkan sikap memegang komitmennya untuk menterinya tidak boleh merangkap jabatan sebagai pemimpin partai politik, dan membentuk pemerintahan profesional bukan bagi-bagi kursi. Kekhawatiran pemerintahan kembali mengalami "gunjangan" serta persiapan di tahun politik menjelang Pemilihan Umum Presiden (Pilpres) 2019, menjelaskan realitas bahwa Jokowi menunjukkan kelonggaran (dalam reshuffle keempat) setelah memperbolehkan dua menteri dari Golkar untuk merangkap jabatan di partai politik, yakni Menteri Perindustrian Airlangga Hartarto merangkap sebagai Ketua Umum Partai Golkar dan Menteri Sosial Idrus Marham sebagai Sekretaris Jenderal Partai Golkar. Pilihan sikap Jokowi ini sejalan dengan kesepakatan Golkar yang menyatakan mendukung Jokowi untuk kembali maju sebagai calon presiden (Capres) dalam Pilpres 2019 mendatang. Di sisi lain, Presiden Jokowi tidak mendepak PAN dari kabinet kerja, meski PAN sering tak sejalan dengan program Presiden Jokowi seperti, menolak pemberlakuan ambang batas pencalonan presiden (presidential threshold) dan menolak penetapan Peraturan Pemerintah Pengganti Undang-Undang tentang Organisasi Kemasyarakatan menjadi undang-undang, (Koran Tempo, 2 November 2017).

Ternyata permasalahan pelik dari pemerintahan Jokowi bukan hanya hubungan Presiden dengan DPR, tetapi juga antara pola hubungan suprastruktur dan infrastruktur politik. Antara suasana kehidupan politik pemerintah (organisasi sistem pemerintahan) atau suprastruktur politik dengan suasana kehidupan politik rakyat (organisasi-organisasi kekuatan sosial politik) atau infrastruktur politik yang mana keduanya dalam praktik pemerintahan sehari-hari kedua bidang 
kehidupan ini memunyai hubungan yang saling memengaruhi. Misalnya, Jokowi harus merespons bantuan dukungan relawan yang aktif dalam pemenangan Jokowi-JK, sehingga pemerintahannya pun memberikan bagian untuk relawan-relawan pendukung untuk menduduki kursi BUMN (Leo Agustino, 2015).

Tantangan politik yang lebih rumit adalah hubungan Presiden dengan partainya sendiri, PDI Perjuangan. Ketua Umum PDI Perjuangan Megawati Soekarnoputri merasa Presiden Jokowi sebagai petugas partai, maka Jokowi harus menjalankan keputusan dari partai melalui langsung ataupun tidak langsung arahan Ketua Umum PDI Perjuangan dan rajin melapor kepadanya.

PDI Perjuangan dan pemimpin partai itu juga punya agenda yang belum tentu cocok dengan agenda pemerintah, meski secara normatif tentu sejalan. Dukungan PDI Perjuangan, misalnya, kepada calon Kepala Kepolisian Komisaris Jenderal Budi Gunawan, termasuk dalam konflik Budi Gunawan dengan KPK, adalah contoh bahwa agenda partai utama pendukung Presiden tidak mudah disesuaikan dengan agenda Presiden dalam upaya pemberantasan korupsi, serta agenda Presiden untuk memperoleh wilayah dukungan dari masyarakat sebagai bentuk proses terjadinya input terhadap rezim dan pemerintahannya. Hal yang sama seperti, upaya pelemahan KPK, melalui revisi UU KPK, justru dimotori oleh kader PDI Perjuangan di DPR yang bertentangan dengan aspirasi dari masyarakat untuk penguatan KPK, (Djayadi Hanan, 2015).

Jika melihat kinerja sistem politik yang dijalankan oleh pemerintahan Jokowi adalah berupaya mempertemukan di antara berbagai kepentingan misalnya antara kepentingan partai dan kepentingan masyarakat, konsep win-win solution yang menjadi pilihan dari pola Jokowi mengelola wilayah dukungan, (Elaborasi dari berbagai sumber data: Djayadi Hanan, 2015; Ikhsan Darmawan, 2015; dan Bivitri Susanti, 2016). Arah Jokowi dalam kepemimpinannya tentu pula harus dilihat bahwa telah terjadinya politik akomodasi dan transaksional dalam memerintah, ini juga menunjukkan bahwa Jokowi merupakan pemimpin yang tak naif terhadap dukungan politik (Koran Tempo, 26 Oktober 2015).

B. Pengelolaan Hubungan dengan Lingkungannya (Domestik dan Internasional)

Hubungan antara sistem politik dengan lingkungannya sangatlah erat, berintreaksi dengan lingkungan, menunjukkan hubungan memengaruhi maupun dipengaruhi. Pengaruh lingkungan yang masuk ke dalam sistem politik berupa input yang bersifat tuntutan maupun dukungan, 
sedangkan hasilnya yang berupa output (keputusan atau kebijakan) berpengaruh pula ke dalam lingkungan masyarakatnya, (Nazaruddin Sjamsuddin dkk, 1988).

Indonesia sebagai negara kesatuan menunjukkan pusat dan daerah dalam lingkup satu manajemen pemerintahan. Implikasi dari pandangan ini adalah masih dirasakan perlunya pengawasan, nasehat atau bahkan arahan dari pemerintah pusat. Meski begitu, harus diakui bahwa problem utama memerintah negara adalah aspek penetrasi kebijakan. Bagaimana kebijakan-kebijakan yang diambil pemerintah dapat efektif dilaksanakan di level wilayah dan warga negara (Parafrasa: Seta Basri, 2012).

Pemerintah Jokowi memang menunjukkan komitmennya untuk lebih memperhatikan aspek pembangunan ekonomi di daerah misalnya terkait dengan upaya pemerintah menyamakan harga BBM di semua wilayah, meski belum terealisasi sempurna. Menyeragamkan harga bahan bakar secara nasional bukanlah masalah untung-rugi. Kebijakan pemerintah yang sudah semestinya dilakukan itu harus dilihat sebagai usaha meningkatkan kesejahteraan. Banyak penduduk yang tertinggal secara ekonomi, seperti di Papua dan di daerah lainnya, karena bertahun-tahun terbelenggu oleh mahalnya harga BBM.

Upaya yang dilakukan Jokowi ini menginginkan ada keseimbangan antara Indonesia barat, tengah, dan timur. Keseimbangan itu setidaknya dalam tiga hal, yaitu infrastruktur, pertumbuhan ekonomi dan pertumbuhan industri. Sebab, misalnya, pertumbuhan ekonomi Papua terganggu karena biaya industri terlalu tinggi. Sehingga dengan satu harga BBM tentu akan menarik investor, juga akan berdampak mendorong berkembangnya perekonomian di daerah (Koran Tempo, 19 Oktober 2016).

Dari kasus ini menunjukkan besarnya perhatian Presiden, terhadap Papua yang memang telah diakui semua pihak. Hal ini tercermin dalam komitmennya untuk mengunjungi Papua tiga kali pertahun serta upaya mempercepat pembangunan ekonomi dan infrastruktur di Provinsi Papua dan Papua Barat. Di samping itu, juga menunjukkan para pengambil/pembuat kebijakan dalam sistem politik Indonesia sekarang ini telah mampu mengenali semua potensi kekayaannya dan permasalahan yang terjadi di daerah dalam rangka pembuatan keputusan mengenai pengembangan wilayah, atau keputusan ekonomi, sekaligus menunjukkan kepedulian pemerintah pusat untuk pembangunan ekonomi dan kesejahteraan di daerah-daerah. Meskipun kebijakan itu adalah bagus dan berani, namun ada tiga potensi masalah yang perlu diasuh agar dampaknya 
seminimal mungkin seperti, penentuan titik lokasi penyalur, pemilihan moda mata rantai pasok, dan mitigasi dampak pertumbuhan konsumsi dan biaya, (Koran Tempo, 1 November 2017).

Sayangnya, masih banyak pekerjaan berat yang menghadang pemerintahan Jokowi seperti dalam pengelolaan ekonomi di dalam negeri, kenaikan harga kebutuhan pangan menyebabkan permasalahan di tingkat pemenuhan kesejahteraan rakyat, seperti: harga daging sapi segar sebelum lebaran (tahun 2017) dan sesudah lebaran atau hingga sekarang masih tinggi sekitar $120.000 \mathrm{per} / \mathrm{kg}$, begitu juga harga beras secara perlahan sudah terjadi kenaikan sejak akhir November 2017 lalu hingga mencapai titik tertinggi pada awal 2018 sehingga pemerintah mengeluarkan kebijakan impor beras 500.000 ton beras yang dilakukan demi memperkuat cadangan beras nasional, (http://nasional.kompas.com/read/2018/01/16/09133911/ini-alasanpemerintahan-jokowi-impor-500000-ton-beras).

Sistem politik Indonesia juga harus memahami pengaruh sistem-sistem politik lain, atau dalam hubungan internasionalnya. Dalam pola hubungan internasional ini masing-masing sistem politik berupaya memperjuangkan kepentingan nasionalnya. Kekeliruan di dalam mengambil kebijakan luar negeri akan menimbulkan gangguan bagi sistem politik sendiri, (Nazaruddin Sjamsuddin, 1988). Dalam konteks kepentingan Indonesia, Presiden Jokowi telah menegaskan Indonesia siap melanjutkan kerja sama yang saling menguntungkan. Jokowi juga memperlihatkan upaya membangun perdamaian dan menciptakan kesejahteraan dunia, tetapi juga berupaya menunjukkan dan melindungi kedaulatan Indonesia. Misalnya meskipun ditentang dunia, Jokowi tetap melanjutkan eksekusi hukuman mati terhadap terpidana kasus narkoba hingga dilakukan sampai dengan tiga jilid. Kebijakan ini dapat kita anggap bahwa negara tidak serta merta dianggap bertentangan dengan HAM, tetapi tindakan itu perlu dilakukan negara karena negara berusaha melindungi ketertiban umum dan keadilan umum, sehingga bentuk hukuman mati merupakan bentuk pengayoman negara terhadap warga negara terutama hak-hak korban apalagi situasi Indonesia masih darurat narkoba. Meski sayangnya, tak ada bukti nyata jenis hukuman kejam itu mengurangi kejahatan narkotik malah pelanggaran dan penindakan oleh Badan Narkotika Nasional (BNN) dari waktu ke waktu terus bertambah, baik kualitas maupun kuantitasnya, (Koran Tempo, 20 Oktober 2016).

Sistem politik di era pemerintahan Jokowi juga menunjukkan eksistensi Indonesia di kancah internasional seperti berupaya untuk membangun perdamaian dunia, melalui 60 Tahun 
KTT Asia Afrika dihasilkan komitmen untuk mendukung kemerdekaan negara Palestina. Melalui Deklarasi Palestina juga mengajak seluruh negara Asia dan Afrika untuk bersatu dalam rasa persaudaraan dan solidaritas, serta membantu pembangunan infrastruktur Palestina yang telah hancur karena serangan Israel utamanya di Jalur Gaza dan mendukung Palestina sebagai anggota tetap PBB.

\section{Proses Pengelolaan Sistem Politiknya}

Pembahasan berikut mengenai interaksi politik dalam kehidupan masyarakat. Upaya ini dilakukan untuk menjelaskan bahwa terus bekerjanya sistem itu dalam pola mekanisme kerja sistem politik. Di awal telah dijelaskan bahwa pemerintah Jokowi begitu serius melakukan proses konsolidasi politik, disamping itu pembangunan ekonomi secara merata dikedepankan ini semua merupakan harapan dari diperolehnya dukungan terhadap personal, rezim, dan pemerintah.

Sehingga tak jarang Jokowi melalui pemerintahan harus membuat landasan bagi posisinya dengan menciptakan suatu suasana pemikiran yang dapat memperoleh dukungan di kalangan warga negaranya. Dalam kasus ini bisa terlihat ketika Presiden memilih opsi kedua untuk “merelakan" melengserkan Archanda Tahar atas masalah kewarganegaraan ganda yakni sebagai warga negara Indonesia dan Amerika Serikat dalam waktu bersamaan, sehingga Arcandra tercatat dalam sejarah sebagai menteri dengan jabatan terpendek dari menjabat (menggantikan Sudirman Said) hingga dicopot dari Menteri ESDM, tidak sampai 20 hari atau kurang dari sebulan.

Namun setelah memperbaiki administrasi kewarganegaraannya atau setelah dipulihkan statusnya sebagai warga negara Indonesia oleh Menteri Hukum dan HAM, maka Arcandra diangkat lagi menjadi menteri, meski dengan pilihan yakni menambah posisi kursi Wakil Menteri untuk mengakomodir Arcandra Tahar dalam pos kementerian menteri energi dan sumber daya mineral (Parafrasa: Majalah Tempo, 22-28 Agustus 2008), menariknya pengganti Arcandra sebagai menteri ESDM adalah Ignasius Jonan yang belum lama terkena reshuffle jilid II. Kasuskasus seperti Arcandra ini banyak terjadi di pemerintahan Jokowi, sebut saja kasus lainnya Komisaris Jenderal Budi Gunawan yang gagal jadi kapolri tetapi digeser menjadi kursi wakapolri, jenjang berikut dari karir Budi Gunawan adalah sebagai Kepala BIN.

Dalam kasus ini ingin mengarahkan perhatian bahwa pada adanya kebutuhan suatu pemerintahan akan dukungan bila ingin memiliki kemampuan untuk membuat keputusan berdasar tuntutan-tuntutan yang diajukan kepadanya. Namun, sudah tentu, suatu pemerintahan 
dapat menarik dukungan dengan berbagai cara seperti contoh di atas, upaya yang dilakukan Jokowi sebuah persetujuan sekaligus dengan mengalihkan posisi dari aspek tuntutan oleh masyarakat.

Sistem pemerintahan yang dipilih Jokowi adalah merawat dukungan politik bagi Presiden, rezim, dan pemerintahannya. Upaya-upaya ini dilakukan dengan beragam cara dari blusukan, teleconference, serta melakukan safari politik ketika untuk meredam gejolak tuntutan dari masyarakat terhadap sistem politik. Lihat saja, ketika terjadi kasus penistaan agama yang dianggap dilakukan oleh Ahok dalam pidatonya di Kepulauan Seribu, Jokowi melakukan safari politik menemui Prabowo Subianto eks pesaingnya dalam Pilpres dua tahun lalu, instutisi keamanan negara dan mendatangi sejumlah tokoh Islam serta organisasi Islam seperti Kantor NU, Muhammadiyah, dan pertemuan dengan para ulama. Safari politik Jokowi ini dilakukan dengan tujuan menjaga kemajemukan Indonesia.

Tradisi silaturahim memang dipilih oleh Jokowi dalam meredam gejolak tuntutan dari masyarakat, merawat keutuhan negara kesatuan, serta untuk meredam perseteruan politik, ini telah ditunjukkan Jokowi dari awal sebelum ia menjabat sebagai Presiden. Misalnya, Jokowi merespons dengan baik melalui upaya melakukan konsolidasi politik antarpemimpin politik, kala itu Jokowi mendatangi Prabowo yang sedang berada di kediaman mendiang bapaknya, Sumitro Djojohadikusumo, di Jakarta Selatan, bertepatan dengan ulang tahun Prabowo yang ke-63. Upaya ini dilakukan untuk menghentikan perseteruan politik, akhirnya, keduanya juga sepakat untuk menghentikan perseteruan politik, tentu saja pertemuan keduanya melumerkan segala kecurigaan upaya penjegalan pelantikan Jokowi, (Majalah Detik, 2014).

Pemerintahan Jokowi meski bisa saja memaksakan penyelesaian-penyelesaian atas tuntutan-tuntutan sekalipun tidak mendapat dukungan, yaitu dengan ancaman penggunaan kekuatan kekerasan tetapi ini tidak dilakukannya. Sepertinya ia menyadari bahwa suatu pemerintahan yang didasarkan atas penggunaan kekerasan semata-mata tidak akan dapat bertahan lama dalam dunia seperti sekarang ini, (Parafrasa: Mochtar Mas'oed dan Colin MacAndrews, 2001).

Respons kerja sistem politik di bawah pemerintahan Jokowi dapat dikatakan sangat melihat arus kepentingan dan kebutuhan masyarakat. Misalnya, ketika pemerintah mengeluarkan kebijakan Peraturan Pemerintah Pengganti Undang-Undang (Perpu) Nomor 1 Tahun 2016 
tentang Perubahan Kedua atas UU Nomor 22/2002 tentang Perlindungan Anak, yang meski terjadi pro-kontra, tetapi akhirnya telah berhasil disahkan menjadi undang-undang. UU itu dianggap bisa menurunkan angka kekerasan terhadap perempuan dan anak karena hukuman yang diberikan untuk kasus ini dianggap mampu memberikan efek jera, sebab adanya hukuman mati, seumur hidup, dan hukuman kebiri. Hadirnya Perpu ini diawali dari respons pemerintah atas menyusul terjadinya kasus kekerasan seksual yang menimpa bocah SMP, Yuyun di Bengkulu, (Koran Tempo, 13 Oktober 2016).

Meski demikian, kinerja legislasi yang merupakan sebuah keputusan bersama antara pemerintah dan DPR (lihat, Pasal 20 ayat (2) UUD NRI 1945) ternyata produk legislasi (sebagai output) dianggap sangat tak memuaskan bahkan dianggap "darurat legislasi" akibat rendahnya jumlah produk legislasi, dari 50 target RUU hanya tercapai 9 RUU yang berhasil disahkan menjadi UU pada November 2016 dan begitu juga diakhir tahun 2017 lalu, bahkan diprediksi tahun 2018 ini hingga 2019 mendatang kinerja legislasi bakal lebih buruk mengingat merupakan tahun politik menjelang Pemilu Serentak 2019 nanti.

Buruknya kinerja legislasi terjadi karena banyaknya target RUU, padahal setiap tahun tak pernah tercapai. Situasi ini juga dicurigai banyaknya target RUU hanya untuk menghamburhamburkan anggaran sebab anggaran satu pembahasan UU sebesar Rp 6 miliar, negara harus mengalokasikan Rp 300 miliar untuk 50 target legislasi, (Koran Tempo, 18 November 2016).

Jika berbicara legislasi sebagai output-output khas dari suatu sistem, maka pada pemerintahan terletak tanggung jawab tertinggi untuk menyesuaikan atau menyimbangkan ouput berupa keputusan dengan kebutuhan masyarakat (input) berupa tuntutan atas pengaruh lingkungan (internal dan eksternal) dalam masyarakat yang memerlukan perhatian dan respons pemerintah. Buruknya kinerja legislasi di DPR juga menunjukkan kurangnya koordinasi yang baik antara pemerintah dengan partai-partai koalisi pendukung pemerintah, ini menunjukkan kecenderungan kuat bahwa koalisi memang hanya terbatas pada dukungan terhadap presiden untuk memperoleh bagi-bagi kekuasaan tetapi tidak disertai untuk urusan politik lainnya, meski itu demokrasi masing-masing (partai) tetapi menunjukkan kurang etis atau malah jangan-jangan itu menunjukkan lemahnya koordinasi pemerintah dengan koalisi partai pendukung pemerintahan. 


\section{KESIMPULAN}

Jika melihat kinerja sistem politik yang dijalankan oleh pemerintahan Jokowi adalah berupaya mempertemukan di antara berbagai kepentingan misalnya antara kepentingan partai dan kepentingan masyarakat, antara kepentingan pemerintah dengan kepenting an masyarakat, konsep win-win solution yang menjadi pilihan dari pola Jokowi mengelola wilayah dukungan. Meski Jokowi memilih konsep win-win solution namun adakalanya, dalam kepemimpinan Jokowi juga menunjukkan sikap untuk menarik dukungan dengan berbagai cara seperti contoh Arcandra Tahar dan Komisaris Jenderal Budi Gunawan, upaya yang dilakukan Jokowi adalah sebuah persetujuan sekaligus dengan mengalihkan posisi dari aspek tuntutan oleh masyarakat. Ini juga menunjukkan bahwa respons kerja sistem politik di bawah pemerintahan Jokowi bisa dikatakan sangat melihat arus kepentingan dan kebutuhan masyarakat.

Dalam respons terhadap lingkungan seperti domestik dan internasional menunjukkan bahwa Jokowi ingin mewujudkan kesejahteraan dengan membuat kebijakan yang dapat terjadinya keseimbangan antara Indonesia barat, tengah, dan timur, seperti kasus menyeragamkan satu harga BBM. Di samping itu, pemerintahan Jokowi dalam hubungan dengan lingkungan internasional ingin menunjukkan dan mewujudkan kedaulatan Indonesia, serta turut berperan aktif dalam kancah politik internasional dengan tetap berpegang pada politik luar negeri Indonesia yang bebas aktif.

Dalam kepemimpinan Jokowi tentu pula harus dilihat bahwa telah terjadinya politik akomodasi dan transaksional dalam memerintah, ini menunjukkan pula bahwa Jokowi merupakan pemimpin yang tak naif terhadap dukungan politik serta menunjukkan bahwa pemerintahannya mengedepankan konsolidasi politik dan ekonomi. Dari seluruh pembahasan penelitian ini, penulis beragumen bahwa pemerintahan Jokowi-JK saat ini telah cukup berhasil membuktikan konsistensi kinerja dan kerjanya yang merupakan implementasi dari semangat yang digulirkannya sebagai kabinet kerja, sehingga wajar jika pemerintahan Jokowi memperoleh surplus dalam legitimasi karena didukung oleh masyarakat dan elite dari partai politik pendukung pemerintahan, meski tak bisa dimungkiri bahwa kabinet Jokowi mulai menunjukkan minimnya prestasi malah ingkarnya akan komitmen dan prinsip dari pemerintahannya, ini bisa dikarenakan terkurasnya konsentrasi Jokowi untuk tetap menjaga kestabilan pemerintahan. 


\section{DAFTAR PUSTAKA}

\section{A. Buku}

Asshiddiqie, Jimly, Perkembangan dan Konsolidasi Lembaga Negara Pasca Reformasi, Jakarta: Sinar Grafika, 2012.

Basri, Seta, Sistem Politik Indonesia, Depok: Indiepublishing, 2012.

Darmawan, Ikhsan, Analisa Sistem Politik Indonesia, Bandung: Alfabeta, 2013.

Faisal, Sanipah, Penelitian Kualitatif: Dasar-dasar dan Aplikasi, Malang: YA3 Malang, 1990.

Fatah, Eep Saefulloh, Gambar Skema Sistem Politik Indonesia, 2014.

Hanan, Djayadi, Menakar Presidensialisme Multipartai Di Indonesia: Upaya Mencari Format Demokrasi yang Stabil dan Dinamis dalam Konteks Indonesia, Bandung: Mizan, 2014.

Herdiansyah, Haris, Metodologi Penelitian Kualitatif untuk Ilmu-ilmu Sosial, Jakarta: Salemba Humanika, 2010.

Heywood, Andrew, Politik (Edisi Keempat), Yogyakarta: Pustaka Pelajar, 2014.

Maksudi, Beddy Iriawan, Sistem Politik Indonesia, Pemahaman Secara Teoretik dan Empirik, Jakarta: RajaGrafindo Persada, 2013.

Mas'oed, Mohtar, dan MacAndrews, Colin, Perbandingan Sistem Politik, Yogyakarta: Gadjah Mada University Press, 2001.

Sjamsuddin, Nazaruddin, Hamid, Zulkifli, dan Pribadi, Toto, Sistem Politik Indonesia, Jakarta: Karunika, 1988.

\section{B. Artikel Jurnal, Surat Kabar, dan Sumber Online}

Agustino, Leo, Satu Tahun Pemerintahan Jokowi: Transaksional dan Transformasional, dalam Analisis CSIS, Vol. 44, No. 4/2015.

Efriza, Gaya Kepemimpinan dan Komunikasi Politik Jokowi, dalam Prosiding Seminar Nasional ke-13 STIP-AN Tahun 2017, "Membangun Kualitas dan Karakter Pemimpin Pemerintahan sebagai Pamong Bhineka Tunggal Ika,” Jakarta, 20 September 2017.

Hanan, Djayadi, Setahun Pemerintahan Joko Widodo Tiga Tantangan Jokowi, dalam Koran Tempo, 27 Oktober 2015.

Lesmana, Tjipta, Tuna-Empati: Kelemahan Utama Pemimpin Indonesia, dalam Jurnal Politika, Menimbang Kepemimpinan Politik, Vol. 10, No. 1/2014. 
Koran Tempo, Pengesahan Perpu Kebiri, Pemerintah Siapkan Tiga Aturan Pelaksana, 13 Oktober 2016.

Koran Tempo, BBM Satu Harga Di Papua, 19 Oktober 2016.

Koran Tempo, Editorial: Bunga-bunga Dua Tahun Jokowi, 20 Oktober 2016.

Koran Tempo, Kubu Trump Wacanakan Pendataan Imigran Muslim, 18 November 2016.

Koran Tempo, Jokowi Belum Berniat Depak PAN, 2 November 2017.

Koran Tempo, Setahun Konsolidasi Politik, 26 Oktober 2015.

Majalah Tempo, Heboh Menteri Indo-Amerika, 22-28 Agustus 2016.

Majalah Detik, Optimisme Baru, Edisi 151, 20-26 Oktober 2014.

Warta Kota, Koalisi Partai Politik Pendukung Pemerintah: KIH Ganti Nama Jadi P4, 14 November 2015.

Kuwado, Fabian Januarius, Ini Alasan Pemerintahan Jokowi Impor 500.000 Ton Beras, dalam http://nasional.kompas.com/read/2018/01/16/09133911/ini-alasan-pemerintahan-jokowiimpor-500000-ton-beras, (diakses tanggal 12 Februari 2018)

\section{Wawancara}

Darmawan, Ikhsan, dosen ilmu politik Universitas Indonesia, tanggal 27 Oktober 2015, Jakarta.

Susanti, Bivitri, Dosen Hukum Tata Negara di Sekolah Tinggi Hukum Indonesia Jentera, tanggal 8 Januari 2016, Jakarta. 